\title{
Negotiation of Personal Service Contracts
}

\section{Gordon Youngman*}

THIS PAPER will discuss only contracts for the employment of talent, viz., -actors, writers, directors and producers, since all other employment is covered by collective bargaining contracts. Before considering any individual contract however, it is essential to read the particular guild contract relating thereto. ${ }^{1}$

When the contract is for an actor to appear in one picture for a salary of less than $\$ 25,000$, the Screen Actors Guild enforces the use of a printed form of contract which it has approved and which cannot be modified except for the benefit of the actor. This contract is very favorable to the actor, so this is no hardship to one negotiating an employment agreement in behalf of an actor. It is to be noted that the $\$ 25,000$ relates to cash compensation paid during production and if the actor is to receive cash plus a deferment or cash plus a percentage of receipts or net profits, in computing whether the compensation is $\$ 25,000$, only the cash may be considered. For example, if an actor is to receive $\$ 20,000$ in cash, $\$ 30,000$ as deferred compensation to be paid after the cash negative cost of the picture is recovered, and $10 \%$ of the net profits, under the interpretation of the Screen Actors Guild, this is still a contract for less than $\$ 25,000$.

In using the Screen Actors Guild minimum contract form about the only important matter to negotiate will be the screen and advertising credit to be afforded the actor.

The Screen Writers Guild and the Screen Directors Guild have not specified any particular form of contract, but they do have certain mimimum provisions which must go into various types of contracts, such as minimun salaries, maximum hours of work, etc.

It is to be noted that many of the provisions of all employment contracts recite the presently existing law. When a contract is presented, excerpts from the codes will be recognized.

* Member, Los Angeles Bar.

1 The Screen Actors Guild has a basic agreement covering employment in theatrical motion pictures. It also has a supplement covering television films, a supplement covering educational films and a supplement covering filmed commercials for television programs.

The Screen Writers Guild has a basic agreement covering work in connection with theatrical motion pictures and a supplement covering services in television films.

The Screen Directors Guild has a basic agreement covering work in motion pictures and a supplemental rate schedule covering minimum salaries for work in television films.

The Screen Producers Guild has not as yet endeavored to cover any basic form of employment contract. 


\section{Term Employment Contracts}

In term employment contracts by a studio, the employment is almost always for a term of six months or one year with options to renew, exercisable in the case of a six months' option upon fifteen days' notice and in one year's option upon thirty days' notice. In this connection, Sections 3001 and 3003 of the Labor Code should be considered. Section 3001 provides in effect that the period of payment determines the period of hiring, and 3003 provides that if a term contract expires and the parties continue to perform under it, it is presumed to be renewed for the same term at the same salary. Some employment contracts contain clauses which specifically provide that these sections do not apply to the contract, but if the contract presented does not so provide, consideration should be given whether the sections will be beneficial or detrimental to the client. This will depend upon the demand for him in the market.

The practice of a studio in committing only for a short period and taking successive options for a number of additional periods was upheld by the Supreme Court of California in Warner Bros. Pictures, Inc. v. Joan Brodel. ${ }^{2}$

A term contract always provides for "layoffs," which are vacations without pay. The usual layoffs are six weeks out of twenty-six or twelve weeks out of fifty-two. The various guild contracts provide for certain maximum layoffs and for periods of minimum consecutive layoff. Layoffs of actors and directors must be for a consecutive period of not less than one week, unless the period remaining is less than a week, and layoffs of writers must be for not less than three consecutive weeks unless the period remaining is less than three weeks. It is to be noted here that under the guild agreements various services are not considered to break the layoff. For example, an actor may be required to render services in re-takes and added scenes while on layoff, to read scripts, attend publicity interviews, pose for publicity stills or fashion stills, consult with hairdressers, inakeup and wardrobe personnel, test voice, etc. In order to give a client as much of a rest as possible between pictures, provide for as long a period of consecutive layoff as possible, with a provision that any services are to be considered a break of layoff, so that the client cannot be called upon to appear in the studio to render services not considered a break of layoff under the guild agreements. Furthermore, if he wants to leave town during a layoff, the contract must so provide.

\section{Billing}

All employment contracts with employees of any standing provide for mention of the employee on the screen and in advertising and publicity, 
which mention is usually referred to as "billing" or "credit." The Screen Writers Guild and the Screen Directors Guild have specified the forms of credit to be afforded writers and directors. In the case of a particularly prominent writer or director, it is sometimes possible to enlarge upon this form and provide for more prominent credit than that required by the guild. It is to be noted that if more than one writer has worked in connection with the screenplay or story, the guild will determine who gets the credit and its decision is final.

It is important not only to provide what credit an actor will receive, but also to refer to the credit to be given other members of the cast, in order that your client's credit may be proper in relation to such other members of the cast. For example, the contract should specify whether he will receive star or feature credit, whether there shall be any co-stars, the position of the credit to be afforded the co-stars, whether or not the name shall appear above or below the title, whether or not any other member of the cast is to have greater prominence, etc. If he is to receive feature credit, it should be agreed whether first, second, etc. All of this publicity is felt by artists to be of great value and sometimes an actor and even more so a director will undertake a picture for smaller monetary compensation than he otherwise could obtain because the picture and the credit in connection therewith will enhance his career.

The federal court has recognized the value of screen credit in the case of Paramount Productions v. Smith, ${ }^{3}$ where testimony was admitted to show the difference in amounts received for a story sold after screen credit and salary increases after screen credit was received.

\section{Travel and Wardrobe}

Any employment contract for any class of employee, whether for a term or for an individual picture, will provide that if services are to be rendered more than 25 miles from the studio, reasonable round trip transportation, meals and lodging will be furmshed. If your client is of sufficient importance in the industry, this can be embellished by the requirement to furnish Pullman accommodations, first class lodging, automobile hire, etc.

In either term or individual picture contracts the studios endeavor to have actresses furmish their own underwear and modern shoes and hosiery and actors furnish all modern wardrobe. When representing an actor, you should endeavor to provide that he will furnish the wardrobe which he has, but shall not be obliged to purchase any new modern wardrobe. In addition, the studio should be responsible for all damage to any wardrobe furnished by either an actress or an actor.

3 91 F.2d 863 (9th Cir. 1937), cert. deried, 302 U.S. 749 (1937). 


\section{Availability}

Every employment contract provides, in effect, that the employee will be available at all times at the place designated by the employer, will advise the employer of his whereabouts so that he may be reached at any reasonable hour of the night or day and that he will comply with all reasonable rules and regulations in connection with the conduct of the employer's business and render his services conscientiously to the full extent of his ability and as instructed by the employer "in all matters, including those involving artistic taste and judgment." This clause represents approximately the law of California. ${ }^{4}$

In the case of May v. New York Motion Picture Corp., ${ }^{5}$ the plaintiff was consistently late for rehearsals and for actual photography of her roles and, in addition, was not available at times when she had not had notice to report, so that she could not be reached and requested to report. She was sent a written notice to report to the studio every morning not later than eighty-thirty "irrespective of whether you are cast or not," and was told not to absent herself when she thought she was not cast.

The plaintiff failed to report and was discharged for cause.

The court held that the regulation was reasonable even though the actress would be compelled to report on many days when her services would not be used. The court held further that disobedience of a reasonable order is a violation of duty which justifies a recission. It defines a "wilful" disobedience as one incurred intentionally and held that the term "wilful" did not necessarily imply an evil intention on the part of the servant or malice toward the employer but only meant that the servant knew what she was doing and was a free agent. Even though her contract provided that she would enact roles and report for rehearsals upon notification, the employer was entitled to have her present so that it could find her to notify her.

It is to be noted that the court held that as long as the order is a reasonable one, the motive of the employer in giving it is not important, even though given with the expectation that the employee will leave his employ rather than obey.

In the case of Goudal v. C. B. DeMille Pictures Corp. ${ }^{6}$ the court found that the actress was late for work only because of the requirements of the employer with respect to hairdressers, costuming, etc., and found that this

4 CAx. LABOR CODE $\$ 2854$ provides that an employee for a consideration shall use "ordinary care and diligence." Section 2859 provides that the employee "is always bound to use such skill as he possesses, so far as the same is required." CAI. LABOR CODE $§ 2856$ provides: "An employee shall substantially comply with all the directions of his employer concerning the service on which he is engaged, except where such obedience is impossible or unlawful, or would impose new and unreasonable burdens upon the employee."

545 Cal. App. 396, 187 Pac. 785 (1920).

6118 Cal. App. 407, 5 P.2d 432 (1931). 
was not a wilful failure to comply with her contract. The employer also contended that the actress did not perform to the best of her ability, citing instances of arguments with the director and with the officers of the corporation regarding the portrayal of her roles as evidence of this. The court found that the mere fact that the actress argued showed that she was trying to do her best.

Note, however, that in the last analysis, the employer will have the final say as to artistic performance under the form of contract now in use.

In the Goudal case, the court also found an estoppel as to a number of alleged breaches because after the alleged breaches an option for further employment was exercised.

In the case of Bank of America, as Administrators, v. Republic Productions, Inc., ${ }^{7}$ the court found that absence from the studio on Friday, Saturday and all but one hour of Monday was grounds for dismissal. Following Hartman v. Rogers, ${ }^{8}$ the court held that the plaintiff could not recover for services rendered after the last pay day prior to the breach.

In addition to the general services, each type of employment contract provides for specific services to be performed by the actor, director, writer or producer. In an actor's contract, these services often cover the entire field of entertainment. An effort should be inade to limit the type of services which the employee is to perform, viz.--in the case of an actor, consider whether he should be required to perform in legitimate stage productions, vaudeville, personal appearances, television shows, radio shows, prepare phonograph records, etc., or whether he should be paid additional compensation for such services. In the case of phonograph records, if they are to be distributed commercially and their distribution is not limited to the exploitation of the pictures in which he appears, he should receive a royalty from whoever distributes the records.

In view of the fact that all reasonable orders must be obeyed, definition of the services to be performed is of the utmost inportance to the employee.

If the client is an important star, he should request that he have the approval of the roles which he is to portray, the screenplay, the director and the principal members of the cast with whom he is to play. It is often desirable to request that the employer agree to furnish a stand-in, dressing room and, in the case of a female star, a particular hairdresser. In view of the fact that the Screen Actors Guild does not limit the time during which higher salaried people may be called upon to perform, it is desirable to provide for a rest period after night work or to limit the amount of night work, etc.

The Screen Writers Guild contract and the Screen Directors Guild contract limit services in rehearsals, preparation, etc., for the lower salaried

744 Cal. App. 2d 651, 112 P.2d 972 (1941).

869 Cal. 643, 11 Pac. 581 (1886). 
members unless they are paid for their time. In all cases, it is desirable to have some limit on free services. In the case of a weekly employee, this is not so much of a problem, but under a one-picture contract, such services are often requested before the commencement of actual services in the picture.

\section{Employment Extensions}

In most employment contracts, it is provided that if the employee whether a director, actor, writer or producer, is rendering services in connection with a picture, at the end of the term of the contract or at the end of any option period if the next succeeding option has not been exercised, the employer can extend the employment upon the same terms until the completion of the services of the employee. If a contract is about to run out or if an employer does not wish to exercise an option at a higher rate, it will very often commence a picture one or two days before the end of the term and keep the employee two or three months until the picture is finished. The way to guard against this is to provide that a picture camot be started less than a certain number of weeks before the end of a term.

Note that in no event can the employer extend the contract for more than seven years, under Section 2855 of the Labor Code.

\section{Grant of Rights}

Each type of contract contains a grant of rights to the employer which is in effect a grant of the proceeds of the services. In addition, the employer is given rights in the case of an actor to use a double. The Screen Actors Guild has a clause regarding use of a double prescribed in the case of freelance players, which is beneficial to the actor and there is usually no objection on the part of an employer to incorporate that clause in any employment contract. This clause limits doubling to situations where it is necessary for foreign distribution or where the actor cannot perform a particular bit properly and does not give the general right to double an actor in English.

The grant of rights in all cases gives the right to use the name and likeness of the employee for advertising and exploitation. Most contracts are so worded that the employee's name and likeness can be used in connection with commercial products. To protect the employee, it is necessary to have the employer agree that in no event will the employee be made to appear to indorse or sponsor any commercial product without his written consent. This has two benefits to the employee: (a) it prevents him from appearing to sponsor a product with which he does not wish to be associated; and (b) it enables him to derive revenue from the use of his name or picture. Despite the grant of rights to the employer for all purposes, and despite the fact that the employer is given all rights to use scenes photographed, 
under the Screen Actors Guild agreement a motion picture made after August 1, 1948, cannot be broadcast by television unless a new agreement is made between the employer and the Guild.

Both by common law and statute, the proceeds of an employee's services usually belong to the employer. Under Section 26 of the Copyright Act, the employer is the "author" of the works of an employee for hire. Under Section 2860 of the Labor Code, the results of an employee's services belong to the employer. If the employee is to retain any of the proceeds of his work, therefore, this must be specified in the contract. For example, if a writer wants the right to write magazine articles, he must so provide in his contract.

Producers, writers and directors are required to warrant the originality of their work and that it will not infringe any rights or be libelous or slanderous. This warranty should be limited to the work contributed by the client and it should not extend to any material of the employer prepared by others. The employer should hold the client harmless regarding material furnished by the employer.

\section{"Morality Clause"}

All forms of employment contracts contain some sort of "morality clause." This clause is in many instances now broad enough to cover a refusal to answer a question on the grounds of the Fifth Amendment, viz.that it might tend to incriminate. The contracts usually provide that the employer can both cancel the contract as to future services and remove the billing or credit from the film and advertising of pictures theretofore produced. There is always a question of fact as to whether the conduct is really harmful to the employer. If the conduct is harmful to the employer, there is probably a right of cancellation even at common law because the cases on this are fairly broad. ${ }^{\ominus}$

Section 3005 of the Labor Code provides that an employee may be discharged for "misconduct in the course of his service" or for gross immorality, even though such gross immorality is unconnected with his service. In fields other than the entertainment industry employees have been discharged for grossly immoral conduct not in any way related to their business. For example, a railroad conductor was discharged for operating in his off-hours a bar and house of prostitution and his discharge was held to be proper. ${ }^{10}$

\section{Services to Others}

Employment contracts invariably contain a covenant against rendering services for others in certain fields. Generally, this covenant covers services

${ }^{9}$ WIILISTon, Contracts $\$ 1020$ (Rev, ed. 1936) provides that if the behavior of the employee would curtail the business relations of the employer, the employee was unfit for his employment.

10 Adams v. Southern Pacific Co., 204 Cal. 63, 266 Pac. 541 (1928). 
in the entire field of entertainment. Ever since the old English case of Lumley v. Wagner ${ }^{\text {II }}$ courts both in England and America have been willing to enjoin a breach of a negative covenant not to render services of a unique type for other parties. In the case of England, the courts have required a specific negative covenant, but the American courts have tended to imply a negative covenant where the other terins of the contract indicate that it reasonably should be implied.

The covenant cannot run beyond the term of the contract. There is authority for the proposition that it is the unfair competition of the new enployment which was enjoined at common law. Whatever the theory, injunctions were fairly easy to obtain so long as it could be proved that the services were unique and that money damages were inadequate. ${ }^{12}$

There of course can be no specific performance of an employment contract. It would not only be impossible to make an employee perform in a proper manner, but it would undoubtedly violate the Thirteenth Amendment of the U.S. Constitution. In California the situation is unique. Section 2390 of the Civil Code provides that there can be no specific perfornance of a contract for personal services. However, Section 3423 of the Civil Code provides as follows: ${ }^{13}$

An injunction cannot be granted:

... Fifth-To prevent the breach of a contract, other than a contract in writing for the rendition or furnishing of personal services from one to an other where the minimum compensation for such service is at the rate of not less than six thousand dollars per annum and where the promised service is of a special, unique, unusual, extraordinary or intellectual character, which gives it peculiar value the loss of which cannot be reasonably or adequately compensated in damages in an action at law, the performance of which would not be specifically enforced.

From the wording of the section, it would seem that a breach of an enployment contract as such could be enjoined. This would mean that an employee could not elect to remain idle rather than work. If this is so, the section seems to be unconstitutional. A court might imply that the injunc-

111 De G. M. \& G. 604, 42 Eng. Rep. 687 (1852).

12 In the case of Warner Bros. Pictures, Inc., v. Nelson, 53 T.L.R. 14 (K.B. 1936), Warner Bros. endeavored to enjoin Bette Davis from working for a British studio in violation of a negative covenant which provided that for the duration of her contract she would engage in no services for anyone other than Warner Bros. or in any occupation whatever without the plaintiff's consent. The plaintiff requested an injunction only against serving others in the motion picture and theatrical fields. The injunction was granted.

Under the earher English cases, if Warner Bros. had asked for an injunction against rendering any kind of services, the imjunction would not have been granted, but where a defendant can earn a hiving even though not as lucrative a living, in some other line of endeavor, the court felt that an injunction was proper.

13 Caz. Code Crv. Proc. § 526(5). 
tion could be granted only to prevent a breach of the negative covenant in the contract. So far as I have been able to ascertain, this matter has not been decided in California. ${ }^{14}$

In view of the uncertain state of the law in California, it is incumbent upon a lawyer negotiating a personal service contract for an employee to limit the negative covenant to the fields which would be directly injurious to the employer. The standard forms of contracts offered by studios enjoin directors or writers from writing for others or for their own account during the term of the employment and this restiction against writing is not limited to the field of entertainment. Inasmuch as such a clause might be enforceable in California unless a long litigation based on constitutionality were undertaken, it should be limited. The way a clause in such a contract is worded, a writer could be prevented from writing a magazine article or story at home at night. This seems to go far afield from protecting an employer from unfair competition.

In the case of an actor, notion picture and theatrical appearances would, of course, be excluded, but in most cases, it would not be harmful for the actor to appear as a guest on an occasional radio program, or in a night club, to make phonograph records and to perform various other services which would not be calculated to keep people out of motion picture theatres.

\section{Guild Membership Warranty}

Forms of employment contract usually contain a warranty that the prospective employee is a member of the particular guild covering his type of employment. The studios maintain a union shop and to the extent permitted by law, they require employees to belong to their applicable guilds.

\section{Contracts with Minors}

Very frequently contracts are made with minors. Under the common law a minor can disaffirm a contract up to a reasonable time after attaining majority. California has a statute ${ }^{15}$ to the effect that where the contract has been approved by the superior court in the county in which such minor resides or is employed, a contract otherwise valid entered into during minority cannot be disaffirmed upon that ground either during actual minority or thereafter, if it is a contract employing the minor as an actor, actress, or other dramatic performer, or as a participant or player in professional sports. Either party to the contract may petition for such approval. While the obtaining of approval of the superior court is incumbent upon the employer and not the employee, this statute should be considered when a con-

14 The matter of negative covenants and the California situation is discussed in 10 So. CarTr. L. Rev. 347 (1937).

${ }^{15}$ Cat. Crv. Code $\$ 36$. 
tract is negotiated because the client, if an actor or an actress, will be in no position to disaffirm the contract. This statute seems peculiar to California.

\section{Suspensions}

There are three situations in which the employer has the right to suspend an employment contract:

(a) Upon the incapacity of the employee;

(b) Upon the default of the employee; and

(c) Upon an act of God or force majeure.

In the case of incapacity, it is usually provided that if because of physical or mental incapacity and, in the case of an actor, cliange of pliysical appearance, the employee cannot render his services, the employer may suspend immediately. If the incapacity continues for a certain number of days contimuously or for periods aggregating a certain somewliat greater number of days, the employer can cancel.

As long as the periods during which the incapacity must continue before there can be a cancellation are not too short, the incapacity clause has, in effect, certain benefits to the employee. Under the law of most jurisdictions. if an employee is unable to perform his contract, he will not be paid while he is not performing and if he is incapacitated beyond a reasonable period the employer can cancel the contract. What is a reasonable period depends upon the nature of the work involved. In the case of an actor appearing before the cameras, undoubtedly a reasonable period would be a very sliort one.

At cominon law no notice of termination was necessary in the event of an incapacity preventing a substantial performance on the part of the employee.

While the incapacity clause may look harsh, it is probably no more harsh than the common law. Section 2924 of the Labor Code provides for cancellation in the event of "continued incapacity," which is not defined. An endeavor should be made to have the period of incapacity for one individual illness before a cancellation can be had as long as possible and the aggregate periods of illness of a term should of course be longer than the period of one individual illness. If a clause calling for very short periods of incapacity before a cancellation can be had is presented, the employer should be asked to differentiate between an incapacity occurring during actual production of a picture and an incapacity occurring while the employee is not actually engaged in production. Many times a term employee will be waiting for a call to work and should be permitted considerable latitude during such a period if there lias been no actual call.

It is to be noted that the right to suspend is something that does not exist in common law but is a matter of contract only. However, this right 
is in any case probably a benefit to the employee because if the employer did not have the right to suspend it would have no alternative but to cancel the contract. Of course, if the employee is in great demand and could always obtain work elsewhere the employee might prefer to have it cancelled. But, in most cases, it is beneficial to the employee to provide for a suspension. There is nothing in the law which prevents parties from agreeing to treat an incapacity in any reasonable manner and an agreement providing for a suspension is perfectly legal.

The employment contracts usually provide that in the case of suspensions the employer may extend the current term of employment for a period of time equivalent to the aggregate of the periods of suspension. The reason for this is to enable the employer to have the benefit of the employee's current salary rate for the full tern of the employment period. In this connection it is to be noted that even though there have been suspensions, the employee cannot be required to work after a period of seven years has expired from the date of the commencement of the employment, under Section 2855 of the Labor Code. ${ }^{16}$

In the case of disability, the employer keeps the proceeds of the services of the employee up to the time of cancellation and payment of the salary up to the time of disability is full compensation for the services rendered.

Pregnancy is considered an incapacity. It should be provided that the contract may be suspended for pregnancy but cannot be terminated in its entirety.

In the case of a default, the employment contract usually provides that the employer can suspend forthwith and can cancel at any time during the continuance of the suspension and until the default is cured and it is in a position to use the employee's services. For example, if an employee refuses to perform in a picture, the employer can suspend not only until it has cast that particular picture, but until it has another picture ready for the employee, so that it will not be paying him for idle time.

The employer has the same rights of extension as in the case of incapacity.

There is not a great deal that can be done for a client with regard to a default clause. The employer will probably not agree to give written notice of the default because it will argue that this would permit the employee to refuse to come to work every day without being in default until the notice is received. The employer wants great flexibility in the event of a default. The employer will probably agree to limit its rights to suspend and cancel to material defaults, but, in the case of motion picture production, any

${ }^{16}$ DeHaviland v. Warner Bros. Pictures, 67 Cal. App. 2d 225, 153 P.2d 983 (1944) is the leading case on this point. 
failure to report for work or to perform services is, of course, a material default.

Section 2924 of the Labor Code provides for termination of the employment in case of a "wilful" breach by the employee. "Wilful default" has been defined as an act done intentionally and malice is not essential. ${ }^{17}$ The right to suspend, of course, is a broader right than that afforded by law, but no studio will enter into an employment contract without such a right. Suspension is the principal sanction of an employer because a popular star often would be glad to have the contract cancelled.

The act of God or force majeure clause is very broad, and in the event of numerous contingencies the employer has the right to suspend. The clause usually covers interruption of work by reason of law, statute, court order, acts of God, earthquake, flood, fire, epidemic, accident, explosions, casualty, labor troubles, civic disturbance, war, act of a public enemy, delay of a common carrier, inability to obtain sufficient inaterial, labor, transportation, power or other essential commodities, death, illness, disfigurement or incapacity of other members of the cast or the director, or the closing of a substantial number of theatres exhibiting the employer's films for one week or more. If the condition continues for a certain period the employee usually has the right to send the employer a notice of cancellation and the employer must then consider the contract cancelled or reinstate the salary of the employee.

When confronted with this clause, an effort should be made to limit both the contingencies which will permit a suspension to those affecting the use of the client's services, and the period during which the contract may be suspended for the agreed upon contingency.

It is to be noted that the various guilds limit the rights of employers to suspend contracts for disability or force majeure in the case of lower salaried employees. It may be possible to use these guild standards in negotiating for higher salaried employees.

\section{Compensation}

Compensation is usually a weekly salary. The guild contracts provide for minimum compensation for various classes of employees. An employee cannot agree to perform his services in connection with a picture for a flat sum which can result in compensation to him of less than the minimum for the time involved. Even if there is no problem as to minimum salary under a guild contract if the client is employed for a single picture and is presented with a contract providing for a flat sum for services in connection with a picture (viz.- $\$ 50,000$ to direct a picture), the contract should provide that he will render his services for not more than a certain total

17 May v. New York Motion Pictures Corp., 45 Cal. App. 396, 187 Pac. 785 (1920). 
number of weeks which can be divided into the number of weeks contemplated for photography plus time for rehearsals, tests, cutting, editing, etc. Any services beyond the maximum number of weeks should be paid for on a pro rata basis. The number of weeks to be provided for would, of course, depend upon the type of services to be performed. In the case of a producer, it is not unusual to provide that his services in connection with a single picture shall take anywhere from eighteen to twenty-six weeks because the producer must start at the very beginning and continue until the end. The director will not be required as long as the producer but his services will be required at least two weeks before the commencement of photography and it is to the director's benefit to continue his services until the completion of the cutting of the picture so that he can see the results of his handiwork. The services of a writer will be completed by the time the picture is ready for photography. Some writers are fast and some are slow and there is no standard rule as to how long these services can take. The employer usually gives the writer a certain period in which to prepare the screenplay. Actors, of course, are required a few times prior to the commencement of photography for wardrobe, make-up, voice tests, rehearsals, etc., and sometimes are required after the completion of photography for added scenes or retakes, dubbing of sound and publicity stills. Usually an actor's services do not extend more than two or three weeks beyond the contemplated period of photography.

Of course, provision for a weekly conipensation under a term contract offers no problem.

Very often an independent producer will employ an actor, writer or director on the basis that the employee shall receive certain fixed compensation, certain deferred compensation and as a compensation for deferring part of his compensation, a percentage of the profits.

There are two kinds of deferred compensation, one of which is guaranteed by the producer in any event, and the more common kind which is contingent upon earnings. It is, of course, to the advantage of the employee to have the deferment guaranteed.

A deferment for services is usually payable after all of the cash investment, with interest, has been repaid and after any deferments for laboratory work, sound equipment and studio services have been repaid. All deferments for services are usually repaid pari passu. In making an agreement which provides for a deferment, it is essential to learn what all the other deferments are, to whom they are going and how much each of them is. It will then be possible to judge how nuch money will have to be recouped before the employee will have been paid his full salary. If a preferred deferment can be obtained which will come out before other deferments, it is, of course, advantageous. The best thing to do is to have some substantial 
party guarantee the payment of the deferment within a certain period (say eighteen months) after the release of the picture.

If a client is to receive a percentage of the gross receipts or net profits as part of his compensation, great care must be taken in the definition of these items. For one thing, be sure that he is to receive a percentage of the receipts or profits of the particular picture and not of a corporation as an entity. If he receives part of the profits of the corporation, it will be profits after income taxes, after corporate overhead and after all the running expenses of the corporation. The percentage should be payable to the client as a direct payment out of the proceeds of the picture and should be an expense of the corporation.

Many employers try to exclude certain income from the gross receipts. Make sure that the gross receipts include all sums paid as filn rentals where a distributor distributes directly to exhibitors, all sums paid by subdistributors where territorial rights are licensed separately, any income from radio, television, cooperative advertising and all other sources. Specifically include any income on the sale or licensing of positive prints. Some producers im granting a distribution contract for a particular territory, such as, say, Ecuador, will grant the license for a flat sum of, say, $\$ 1,000$, and then sell two prints at $100 \%$ profit. In such a case they would account for only $\$ 1,000$ in gross receipts and pocket the profit on the prints.

After definition of gross receipts, the distribution fee which is to be charged for distribution should be considered. There is no set standard rate for distribution. If the employer is also a distributor, limit the anount which he can charge for distribution in computing net profits. It is better to provide for a fixed figure for a distribution fee rather than to provide that distribution shall be at cost, because cost is almost impossible to determine: Some limit on the number of positive prints to be ordered and the anount to be spent on advertising should be attempted, although, in the last analysis, these matters may have to be left to the judgment of the employer.

In determining the production cost of the picture to be recouped before profits are to be distributed, it should be provided that cost shall be computed in accordance with standard motion picture accounting practices. If possible, a schedule of items such as those to appear in the budget should be attached. In any event, the amount which can be charged by the employer as overhead or indirect charges should be limited, the argument being that the client is sharing in the proceeds for an individual picture and is not to be concerned with the corporation's operation as a corporation. If the client is being employed by one of the larger studios, the overhead charge will probably be a large one, perhaps $30 \%$ or $35 \%$. An independent producer making a picture outside of a major studio will be paying for most of his 
salaries and services on a specific basis so his overhead should be a small percentage, not to exceed say $5 \%$.

It is advisable in a profit sharing deal to specify that the percentage of profits payable to the client shall be that percentage of $100 \%$ of the profits of the picture. If it is provided that the chent shall share a percentage of the profits made by the producer from the picture and the producer has given other profit participations, the client will receive a reduced share. For example, if the producer has given the studio $20 \%$ of the profits and the director $10 \%$, and if the client is entitled to $10 \%$ of the profits, then he will receive only $10 \%$ of $70 \%$, or $7 \%$ of the profits. It is important to be specific that in computing the client's profits $100 \%$ shall be used and no other profit participations shall be taken into consideration.

In this connection it is to be noted that most contracts providing for a participation will provide that the law of California governs those portions of the contract relating to services and grant or rights and that the law of New York will cover those portions relating to distribution and division of profits. The New York law is not substantially different from the California law on the subject of profits.

\section{Right to Appear}

Employment contracts almost invariably provide that the employer will not be required to use the services or the product of the services of the employee and that payment of the compensation to the artist will be full compliance with the contract. This, of course, would not be the case in a contract where the employee had a profit participation. The reason this clause is included is that under various English cases, it is held that the right to appear is an essential part of an actor's contract. The effect of this clause is to waive that right. The employer therefore is permitted to keep an employee up to seven years remaining idle so long as the compensation is paid. If at all possible, one should negotiate a clause to the effect that if a certain period elapses without the employee having rendered services in a picture, the employee shall have the right to cancel.

\section{Rendering Service Outside U.S.}

Contracts often provide that the employee will render services anywhere in the world. If the employee is an American citizen this will not cause any great difficulty. If, however, the client is an alien, it will be necessary to check his status as an immigrant before agreeing to permit him to render services outside of the United States. In the case of any employee, it should provide that he will be reimbursed for any additional taxes which he is required to pay by reason of his services outside of the United States. Many countries have no reciprocal treaties with this country and have 
higher imcome tax rates than this country and the employee is entitled to be protected against additional expense because of foreign service.

\section{Loan-outs}

A term contract invariably provides that the employer can lend the services of the employee to any other person and grant such other party the right to sublend the services. It also provides that the employer can assign the contract and its rights thereunder freely.

If the client is of sufficient stature, a provision that his services shall not be loaned at all without his consent can be obtained. If that is unobtainable, endeavor to obtain a provision that his services can be loaned only to certain named companies or to independent producers distributing their pictures through those companies. If the employee is receiving a percentage of gross receipts or net profits as part of his conpensation, there should be a provision against lending or assignment. There should be the sane restrictions on assignment that there are on lending. While it is the law of California anyway, it is desirable to include a clause that no assignment will operate to relieve the eniployer from liability.

If it is agreed that the enployer shall have the right to lend the services of the employee, ask for half the profits made by the employer on the lending. There have been studios which have made a busmess of lending personalities out at a profit. The average major studio will make a loan-out only occasionally. On the other hand, one organization used to lend the services of its stars far more often than it used them itself and it made a fortune on these lendings. A share in the profits of the loan-out would be a curb on undesirable loan-outs and would prevent the employer fron abusing the loan-out privilege. 